\title{
Aktivitas Gel Fraksi Etil Asetat dari Ekstrak Etanol Daun Ubi Jalar Untuk Pengobatan Luka Bakar
}

Activity of Ethyl Acetate Fraction in Ethanolic Exctract from Sweet Potato Leaves for Burn Treatment

Hanifah Fajar Rahmadani*, Diah Pratimasari, Muhammad Saiful Amin

Program Studi S1 Farmasi, Sekolah Tinggi Ilmu Kesehatan Nasional, Surakarta, Indonesia

*Corresponding author: rfhanifah2412@gmail.com

Submitted: 7 September 2020

Accepted: 2 Maret 2021

Published: 29 Agustus 2021

\begin{abstract}
Background: Burns are an event of loss of tissue caused by contact with a heat source. The use of natural ingredients as a burn treatment replaces drugs with synthetic materials that can have side effects. The natural ingredient that acted as a burn treatment is sweet potato leaves (Ipomoea batatas L.). Objective: This research focuses on using the ethyl acetate fraction from the ethanolic extract of sweet potato leaves as an alternative in the treatment of burns. Methods: The compounds in sweet potato leaves were extracted using $70 \%$ ethanol and fractionated using ethyl acetate as a solvent. Ethyl acetate fraction of sweet potato was identified to see secondary metabolites compounds. The ethyl acetate fraction of sweet potato leaves was formulated in a gel with a concentration of $1 \%, 2 \%$ and $3 \%$. The burn test used a male Wistar strain test animal that had treated with second-degree burns. Burns were made using metal with a diameter of $2 \mathrm{~cm}$ heated on a bunsen fire. Burn observation was carried out every three days by measuring the diameter of the burn. Results: The statistical results showed $p$ value $>0.05$, indicating that there was no statistically significant difference. The qualitatively showed the difference in burn reduction, with the highest graph is obtained by using F2 at 2\% concentration. Conclusion: The ethyl acetate fraction of sweet potato leaves provides activity in treatment of burns.
\end{abstract}

Keywords: burns, fractions, gels, sweet potato leaves

\begin{abstract}
Abstrak
Pendahuluan: Luka bakar merupakan peristiwa hilangnya jaringan yang disebabkan kontak dengan sumber panas. Penggunaan bahan alam sebagai pengobatan luka bakar menggantikan penggunaan obat dengan bahan sintetis yang dapat memberikan efek samping. Bahan alam yang memiliki aktivitas sebagai pengobatan luka bakar salah satunya adalah daun ubi jalar (Ipomoea batatas L.). Tujuan: Penelitian ini berfokus pada penggunaan fraksi etil asetat dari ektrak etanol daun ubi jalar (Ipomoea batatas L.) sebagai alternatif dalam pengobatan luka bakar. Metode: Ekstraksi senyawa dalam daun ubi jalar menggunakan etanol $70 \%$ dan difraksinasi menggunakan pelarut etil asetat. Fraksi etil asetat daun ubi jalar (Ipomoea batatas L.) diidentifikasi untuk melihat senyawa metabolit sekunder. Fraksi etil asetat daun ubi jalar (Ipomoea batatas L.) diformulasi dalam bentuk gel dengan konsentrasi $1 \%, 2 \%$ dan 3\%. Uji luka bakar menggunakan hewan uji tikus galur wistar jantan yang telah diberikan perlakuan luka bakar derajat 2. Pembuatan luka bakar menggunakan logam berdiameter $2 \mathrm{~cm}$ yang dipanaskan pada api bunsen. Pengamatan luka bakar dilakukan setiap 3 hari sekali dengan mengukur diameter luka bakar. Penurunan luka bakar diolah menggunakan Uji One Way Anova dan dibuat grafik penurunan luka bakar. Hasil: Hasil analisa statistik dengan menggunakan Uji One Way Anova menunjukkan nilai $\mathrm{p}>0,05$ yang berarti tidak ada perbedaan signifikan secara statistik. Namun, secara kualitatif
\end{abstract}


menunjukkan trend penurunan luka bakar, grafik tertinggi diperoleh pada pemberian F2 dengan konsentrasi fraksi etil asetat daun ubi jalar (Ipomoea batatas L.) 2\%. Kesimpulan: Fraksi etil asetat daun ubi jalar (Ipomoea batatas $\mathrm{L}$.) memberikan aktivitas pengobatan luka bakar.

Kata kunci: daun ubi jalar, fraksi, gel, luka bakar

\section{PENDAHULUAN}

Luka bakar merupakan peristiwa hilangnya jaringan pada kulit yang disebabkan karena adanya kontak dengan sumber panas seperti air, api, bahan kimia, listrik, dan radiasi. Luka bakar dapat menyebabkan kerusakan kulit dan dapat mempengaruhi system tubuh (Suhada dkk., 2019).

Pengobatan luka bakar menggunakan obat sintetis memiliki aktivitas sebagai antibakteri, antiinflamasi dan analgetik, namun penggunaan obat sintetis memiliki efek samping terjadinya interaksi dengan obat lain, alergi dan beberapa obat sintetis tidak dianjurkan dipakai oleh ibu hamil dan menyusui. Tumbuhan yang berpotensi dalam penyembuhan luka bakar adalah daun ubi jalar (Ipomoea batatas L.) yang memiliki senyawa sekunder seperti flavonoid, saponin dan tanin (Rahim dkk., 2011). Penelitian yang telah dilakukan oleh Lestia \& Marline (2018) dan Rahim dkk. (2011) menunjukkan senyawa flavonoid, saponin, polifenol yang terdapat dalam daun ubi jalar mampu membantu mempercepat penyembuhan luka bakar. Penelitian ini dilakukan fraksinasi menggunakan pelarut etil asetat untuk menarik senyawa flavonoid dari ekstrak etanol daun ubi jalar.

Fraksi etil asetat daun ubi jalar dibuat dalam sediaan gel bertujuan membantu distribusi fraksi, memberikan efek cooling, membantu meningkatkan penetrasi zat aktif yang baik dengan dosis lebih rendah dari ekstrak.

\section{METODE}

\section{Alat dan bahan}

Alat yang digunakan antara lain alat gelas, cawan porselen, bejana, waterbath, oven, loyang, mortir, stamfer, rotary evaporator IKA RV 10, RION viskometer VT-04E, pH meter, alat uji daya lekat, alat uji daya sebar, tabung reaksi , pipet tetes. Bahan-bahan yang digunakan antara lain daun ubi jalar ungu, etanol $70 \%$, etil asetat, n-heksan, aquadest, CMC-Na, propilenglikol, nipagin, lidocain, eter.

\section{Prosedur penelitian \\ Pembuatan simplisia}

Daun ubi jalar ungu disortasi basah, dipisahkan dari kotoran dan bagian tanaman lain, dilakukan pencucian, pengeringan dan sortasi kering.

\section{Ekstraksi}

Simplisia kering yang telah diperkecil ukurannya sebanyak $1 \mathrm{Kg}$ dimasukkan ke dalam bejana, direndam menggunakan etanol $70 \%$ sebanyak $10 \mathrm{~L}$. Maserasi dilakukan selama 5 hari dan diaduk 24 jam sekali selama 1 menit, selanjutnya diremaserasi sebanyak $3 x$ dengan 2,5 L pelarut (Muthmaina dkk, 2017).

\section{Fraksinasi}

Sebanyak 50 gram ekstrak etanol daun ubi jalar ungu dilarutkan menggunakan aquadest hangat $50 \mathrm{~mL}$, diaduk sampai homogen. Ekstrak dimasukkan ke dalam corong pisah, difraksinasi bertingkat dengan metode fraksinasi cair-cair. Fraksinasi menggunakan pelarut non polar yaitu $\mathrm{n}$-heksan sebanyak $50 \mathrm{~mL}$ setiap sekali fraksinasi hingga didapatkan fraksi n-heksan dan fraksi air. Fraksi air yang didapatkan difraksinasi dengan pelarut semi polar menggunakan etil asetat sebanyak $50 \mathrm{~mL}$ setiap sekali fraksinasi, pisahkan fraksi etil asetat. Fraksinasi dilakukan hingga didapatkan larutan bening. Fraksi etil asetat dievaporasi menggunakan rotary evaporator, kemudian dipekatkan di atas waterbath hingga diperoleh fraksi kental (Muthmaina dkk, 2017).

\section{Skrining fitokimia \\ Identifikasi flavonoid}

Sebanyak 0,5 gram fraksi etil asetat ditambahkan $2 \mathrm{~mL}$ etanol $70 \%, 3$ tetes $\mathrm{HCl}$ pekat dan serbuk magnesium 0,5 g. Hasil positif jika perubahan warna menjadi jingga sampai merah yang menunjukkan adanya flavon, dan merah tua sampai merah keunguan yang menunjukkan adanya flavanon (Sulistyawati dkk., 2017). 


\section{Identifikasi alkaloid}

Sebanyak 0,5 gram fraksi etil asetat ditambahkan $2 \mathrm{~mL}$ etanol 70\%, $5 \mathrm{mLHCl} 2 \mathrm{~N}$, kemudian dipanaskan. Dinginkan campuran dan saring. Tambahkan reagen mayer ke dalam filtrat. Warna keruh atau adanya endapan menunjukkan sampel mengandung alkaloid (Sulistyawati dkk., 2017).

\section{Identifikasi saponin}

Sebanyak 0,5 gram fraksi etil asetat ditambahkan $2 \mathrm{~mL}$ etanol $70 \%$ dan $20 \mathrm{~mL}$ aquadest dikocok, didiamkan 15 - 20 menit. Adanya busa stabil selama
10 menit dengan tinggi lebih dari $2 \mathrm{~cm}$ menunjukkan positif saponin (Sulistyawati dkk., 2017).

\section{Formulasi gel}

Aquadest dipanaskan, tambahkan CMC Na aduk sampai homogen. Nipagin dilarutkan dalam propilenglikol, dimasukkan ke dalam campuran CMC $\mathrm{Na}$ aduk sampai homogen, ditambahkan air dan fraksi aduk sampai terbentuk gel (Muthmaina dkk, 2017). Tabel 1 berikut menunjukkan formulasi gel fraksi etil asetat daun ubi jalar.

Tabel 1. Formulasi gel fraksi etil asetat daun ubi jalar (Ipomoea batatas L.)

\begin{tabular}{lcccc}
\hline \multicolumn{1}{c}{ Bahan } & BASIS & F1 & F2 & F3 \\
\hline Fraksi Etil Asetat Daun Ubi Jalar & - & $1 \%$ & $2 \%$ & $3 \%$ \\
Na CMC & $4 \mathrm{~g}$ & $4 \mathrm{~g}$ & $4 \mathrm{~g}$ & $4 \mathrm{~g}$ \\
Propilenglikol & $15 \mathrm{~g}$ & $15 \mathrm{~g}$ & $15 \mathrm{~g}$ & $15 \mathrm{~g}$ \\
Nipagin & $0,18 \mathrm{~g}$ & $0,18 \mathrm{~g}$ & $0,18 \mathrm{~g}$ & $0,18 \mathrm{~g}$ \\
Aquadest ad & $100 \mathrm{~g}$ & $100 \mathrm{~g}$ & $100 \mathrm{~g}$ & $100 \mathrm{~g}$ \\
\hline
\end{tabular}

\section{Kontrol kualitas gel \\ Pengamatan organolep}

Pengamatan organoleptis secara makrokopis dengan memeriksa bau, warna, dan bentuk sediaan. Memiliki beberapa persyaratan yaitu: warna seperti zat aktif, aroma khas daun ubi jalar, penampilan kental (Panji, 2017).

\section{Uji homogenitas}

Gel dioleskan pada gelas objek untuk diamati homogenitasnya. Gel yang homogen harus menunjukkan susunan yang merata dan tidak terdapat partikel yang terpisah (Ulfa, 2016).

\section{Pengukuran pH}

$\mathrm{pH}$ stick indicator dicelupkan kedalam sediaan selama 3 detik. Hasil pengukuran ditunjukkan dengan perubahan warna yang terjadi pada $\mathrm{pH}$ stick indicator (Draelos\& Lauren, 2006).

\section{Uji daya sebar}

Sebanyak 0,50 g sediaan gel diletakkan di atas kaca dan ditutup dengan kaca lain yang telah ditimbang. Selama satu menit kemudian diukur diameter sebaran gel dan diberikan tambahan beban sebesar 25 gram hingga 250 (Ulfa, 2016).

\section{Uji daya lekat}

Gel dioleskan tipis secukupnya pada area $2 \times 2 \mathrm{~cm}$ yang diletakan obyek gelas lain diatasnya. Diberi beban $1 \mathrm{Kg}$ selama 5 menit. Dihitung waktu hingga lekatan terlepas dengan menurunkan beban 80 gram (Panji, 2017).

\section{Uji viskositas}

Gel dimasukkan ke dalam gelas viskometer dan diukur dengan alat pengaduk viskometer nomor 2 . Skala kekentalan sediaan yang diuji akan muncul pada jarum di alat viskometer. Alat yang digunakan adalah RION viskometer VT-04E (Panji, 2017).

\section{Uji luka bakar}

\section{Pengelompokkan hewan uji}

Sejumlah 5 kelompok hewan uji yang terdiri dari 3 tikus tiap kelompok dengan perlakuan:
a. Kelompok I: Kontrol positif (+) gel bioplacenton
b. Kelompok II: Kontrol negatif (-) basis gel
c. Kelompok III: Konsentrasi $1 \%$
d. Kelompok IV: Konsentrasi 2\%
e. Kelompok V: Konsentrasi 3\%

\section{Induksi luka bakar}

Tikus dianestesi lokal dengan krim lidocain. Bulu pada bagian punggung tikus dicukur dengan diameter 2 $\mathrm{cm}$. Panaskan logam berdiameter $2 \mathrm{~cm}$ pada api bunsen selama 1 menit yang kemudian ditempelkan pada punggung tikus selama 5 detik (Ghofroh, 2017).

\section{Analisis data}

Analisis statistik sediaan gel dan diameter luka bakar menggunakan analisis varian satu arah (ANOVA) dengan persyaratan uji normalitas (ShapiroWilk) dan uji homogenitas (uji Levene) menunjukkan nilai p > 0,05 (Muthmaina dkk, 2017). 


\section{HASIL DAN PEMBAHASAN}

\section{Rendemen}

Daun ubi jalar basah sebanyak $5 \mathrm{Kg}$ setelah melalui proses pengeringan menjadi $1 \mathrm{Kg}$ daun ubi jalar kering yang kemudian dimaserasi dan didapatkan ekstrak kental sebanyak 200,1 g dan difraksinasi menggunakan etil asetat sehingga didapatkan fraksi kental sebanyak 50,5 g.

\section{Skrining Fitokimia}

Identifikasi flavonoid memberikan hasil positif dengan menunjukkan perubahan warna jingga. Fraksi etil asetat dilarutkan ke dalam etanol $70 \%$ dan ditambahkan $\mathrm{HCl}$ pekat dan serbuk Mg. Penambahan serbuk $\mathrm{Mg}$ bertujuan untuk menghidrolisis flavonoid menjadi bentuk aglikonnya dengan menghidrolisis $\mathrm{O}$ glikosil, penambahan serbuk $\mathrm{Mg}$ dan $\mathrm{HCl}$ juga akan mereduksi inti benzopiron yang terdapat pada struktur flavonoid hingga terbentuknya garam flavilium. Flavonoid yang tereduksi oleh $\mathrm{HCl}$ pekat dan serbuk $\mathrm{Mg}$ akan memberikan perubahan warna menjadi merah, kuning hingga jingga (Baud dkk., 2014). Gambar 1 menunjukkan reaksi identifikasi senyawa flavonoid.
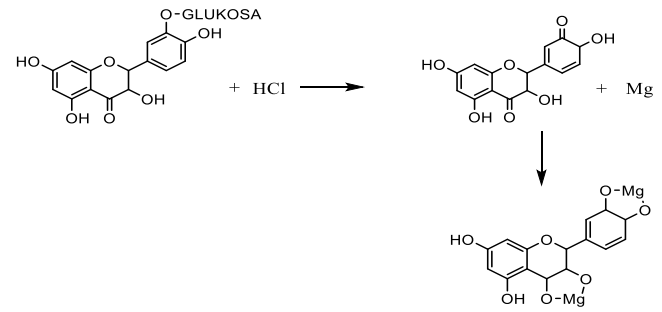

Gambar 1. Reaksi identifikasi senyawa flavonoid

Identifikasi alkaloid dilakukan dengan melarutkan fraksi etil asetat ke dalam etanol $70 \%$ dan tambahkan $\mathrm{HCl}$ pekat untuk menarik alkaloid dari fraksi etil asetat. Alkaloid bersifat basa maka dengan penambahan $\mathrm{HCl}$ pekat akan membentuk garam yang kemudian dipanaskan dengan tujuan memecahkan ikatan antara alkaloid yang bukan bentuk garamnya. Pembentukan endapan alkaloid dilakukan dengan menambahkan pereaksi mayer dan positif terbentuk endapan putih atau larutan berwarna keruh seperti yang dihasilkan dari fraksi etil asetat daun ubi jalar (Widjaya, 2012).Gambar 2 menunjukkan reaksi identifikasi senyawa alkaloid.

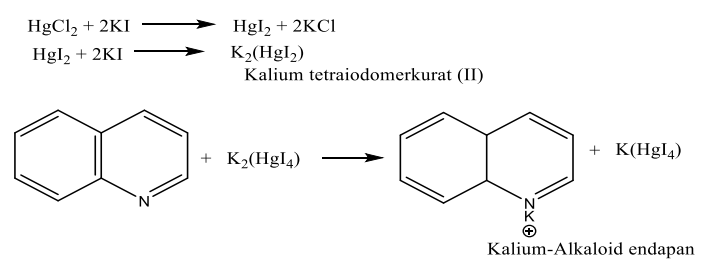

Gambar 2. Reaksi identifikasi senyawa alkaloid
Hasil identifikasi senyawa alkaloid menunjukkan hasil positif dengan terbentuknya larutan berwarna keruh. Uji alkaloid menggunakan pereaksi mayer dapat menyebabkan atom nitrogen pada alkaloid bereaksi dengan ion logam $\mathrm{K}^{+}$yang berasal dari kalium tetraiodomerkurat (II) dan akan membentuk endapan kompleks kalium-alkaloid (Nafisah dkk, 2014).

Hasil identifikasi saponin menunjukkan hasil positif dengan terbentuknya busa stabil lebih dari 30 detik setinggi $1 \mathrm{~cm}$, terbentuknya busa disebabkan oleh glikosida yang mampu membentuk buih dalam air.Gambar 3 menunjukkan reaksi identifikasi senyawa alkaloid.

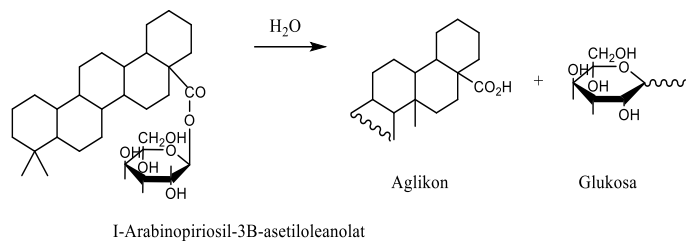

Gambar 3. Reaksi identifikasi senyawa saponin

\section{Kontrol kualitas gel \\ Organoleptis}

Hasil pengamatan organoleptis menunjukkan perbedaan warna, semakin tinggi konsentrasi warna gel akan semakin gelap dan aroma yang dihasilkan semakin tajam.

\section{Homogenitas}

Hasil uji homogenitas pada semua formula menunjukkan hasil yang tidak homogen yang disebabkan karena ketidak larutan fraksi etil asetat dalam air yang memiliki kepolaran berbeda sehingga tidak dapat bercampur.

pH

Sediaan gel fraksi etil asetat daun ubi jalar (Ipomoea batatas L.) F1, F2, F3 dan basis gel memiliki pH 5 yang berarti memenuhi syarat $\mathrm{pH}$ gel yang aman digunakan untuk kulit. $\mathrm{pH}$ gel yang baik memberikan nilai 4,5 - 6,5 jika gel terlalu basa dapat mengakibatkan kulit kering dan jika terlalu asam akan mengakibatkan iritasi pada kulit (Draelos \& Lauren, 2006). Penambahan konsentrasi fraksi etil asetat daun ubi jalar (Ipomoea batatas L.) tidak mempengaruhi $\mathrm{pH}$ sediaan gel.

\section{Daya sebar}

Peningkatan konsentrasi fraksi etil asetat daun ubi jalar (Ipomoea batatas L.) mengakibatkan penurunan daya sebar gel karena konsistensi gel menjadi lebih kental dan jumlah air dalam formula gel berkurang. Hasil daya sebar yang diperoleh memnenuhi persyaratan yaitu $5-7 \mathrm{~cm}$. Hasil uji One Way Anova 
menunjukkan nilai $\mathrm{p}<0,05$ yang bermakna antar formula memiliki perbedaan yang signifikan.

\section{Daya lekat}

Hasil daya lekat gel fraksi etil asetat daun ubi jalar pada formulasi dan basis memunuhi syarat yang ditetapkan yaitu lebih dari 1 detik. Gel yang semakin lama melekat pada kulit dapat meningkatkan banyaknya zat aktif yang diabsorbsi oleh kulit sehingga memberikan efek lebih optimal (Cahyaningsih, 2018). Peningkatan konsentrasi fraksi etil asetat daun ubi jalar (Ipomoea batatas L.) mengakibatkan peningkatan daya lekat gel. Hasil uji One Way Anova menunjukkan nilai $\mathrm{p}<0,05$ yang berarti antar formula memiliki perbedaa yang signifikan.

\section{Viskositas}

Peningkatan konsentrasi fraksi etil asetat daun ubi jalar (Ipomoea batatas L.) yang ditambahkan ke dalam sediaan gel tidak memberikan pengaruh terhadap viskositas gel, hal ini disebabkan karena rentang konsentrasi yang kecil. Hasil viskositas pada keempat sampel menunjukkan nilai yang sama pada spindle nomer 2 yaitu 500 dPa.s sehingga dapat diartikan keempat sampel tidak memiliki perbedaan.

\section{Penurunan diameter luka bakar Inflamasi}

Inflamasi atau peradangan merupakan suatu respon protektif oleh jaringan untuk mengeradikasi mikroorganisme penyebab jejas atau membuang sel dan jaringan nekrotik yang disebabkan oleh kerusakan sel (Yulita, 2018). Berikut Tabel 2 merupakan hasil statistik one-way anova \% penurunan luka bakar.

Tabel 2. Hasil statistik one way anova dari persentase penurunan luka bakar

\begin{tabular}{lccccc}
\hline & Sum of Squares & df & Mean Square & F & Sig. \\
\hline Between Groups & 24369,052 & 4 & 6092,263 & 2,562 &, 070 \\
Within Groups & 47562,089 & 20 & 2378,104 & & \\
Total & 71931,141 & 24 & & & \\
\hline
\end{tabular}

Hasil pengamatan luka bakar fase inflamasi pada F1 terjadi pada hari ke-0 hingga hari ke 5. Fase inflamasi pada F2 terjadi pada hari ke-0 hingga hari ke-4. F3 fase inflamasi terjadi pada hari ke-0 hingga hari ke-4, sedangkan pada kontrol positif terjadi pada hari ke-0 hingga hari ke-5. Luka bakar pada fase inflamasi mengalami pelebaran hal ini disebabkan terjadinya fase hemostatis.

Senyawa alkaloid dalam fraksi memiliki peran sebagai antibakteri yang memiliki mekanisme dalam menganggu komponen penyusun peptidoglikan pada sel bakteri, sehingga lapisan sel tidak terbentuk secara utuh dan menyebabkan kematian sel bakteri. Selain itu juga ada saponin yang memiliki peran sebagai antiseptik dengan mencegah pertumbuhan mikroorganisme.

\section{Poliferasi}

Fase poliferasi memiliki 2 proses penting yang berjalan bersamaan yaitu proses angiogenesi (pembentukan pembuluh kapiler baru) dan penutupan luka bakar yang meliputi re-epitelisasi, pembentukan jaringan granulasi dan deposisi kolagen pada daerah luka.

Fase poliferasi F1 terjadi pada hari ke-6 hingga hari ke-15. Fase poliferasi F2 terjadi pada hari ke-6 hingga hari ke-13. Fase poliferasi F3 terjadi pada hari ke-6 hingga hari ke-13. Fase poliferasi pada kontrol positif terjadi di hari ke-6 hingga hari ke-13. Fase poliferasi kontrol negatif terjadi pada hari ke-6 sampai hari ke-15.

Flavonoid pada daun ubi jalar memiliki peran sebagai antibakteri, antioksidan dan atiinflamasi. Flavonoid bekerja dengan cara meningkatkan pembentukan kolagen, menurunkan edema jaringan, serta meningkatkan jumlah fibroblast. Saponin dalam daun ubi jalar dapat memacu pembentukan kolagen, yaitu protein structural yang berperan dalam proses penyembuhan luka (Fithriyah dkk, 2013).

\section{Remodelling/maturasi}

Fase remodeling merupakan fase penyerapan selsel radang, pembentukan kolagen lanjut, penutupan dan penyerapan kembali pembuluh darah baru, pengerutan luka, dan pemecahan kolagen berlebih.

Fase remodelling yang terjadi pada F1 berlangsung di hari ke-14 pada tikus 1, tikus 2 pada hari ke-15 masih dalam fase poliferasi dan tikus 3 fase remodelling/maturasi berlangsung di hari ke-9. F2 fase remodelling/maturasi berlangsung di hari ke-14 pada tikus 1 dan tikus 3, tikus 2 berlangsung di hari ke-11. F3 fase remodelling atau maturasi berlangsung pada hari ke-14. Fase remodelling atau maturasi pada kontrol positif berlangsung pada hari ke-11 pada tikus 1 dan tikus 3, pada tikus 2 berlangsung pada hari ke-14. Kontrol negatif tidak merngalami fase 
remodelling/maturasi hingga hari terakhir pengamatan karena pada kontrol negatif masih mengalami fase poliferasi. Gambar 4 menunjukkan grafik penurunan diameter luka bakar.

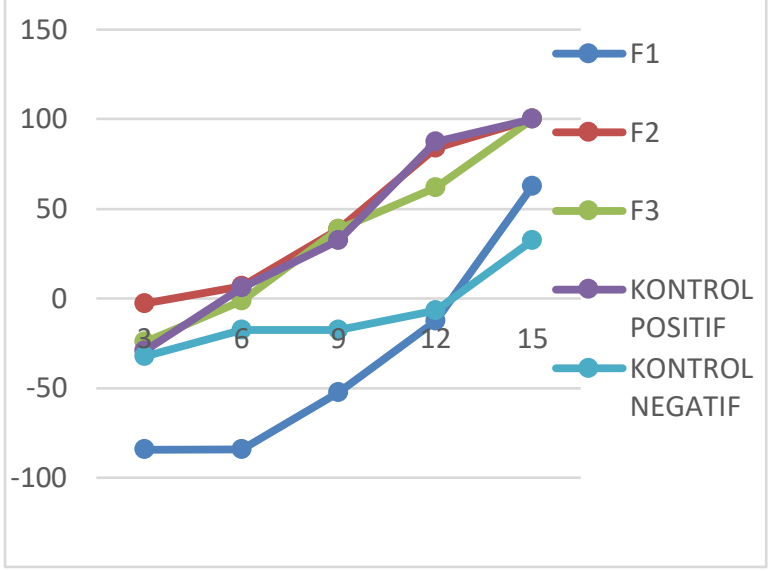

Gambar 4. Grafik persentase penurunan diameter luka bakar

Data \% penurunan diameter luka bakar yang diperoleh selama 15 hari kemudian diolah menggunakan program statistik spss dan dibuat grafik untuk melihat perbedaan hasil $\%$ penurunan diameter luka bakar yang diberikan F1, F2, F3, kontrol positif dan kontrol negatif.

Grafik menunjukkan F2 memberikan hasil yang lebih baik dibanding sediaan gel lainnya. Hal ini dikarenakan pengaruh penambahan penetrasi enhancer propilenglikol. Aktivitas penetrasi enhancer dalam meningkatkan penetrasi zat aktif sediaan gel mencapai kondisi optimum pada F2 dengan konsentrasi 2\%, sehingga peningkatan konsentrasi pada F3 memberikan perbandingan tidak lurus dengan peningkatan aktivitas karena penetrasi dari propilenglikol sudah mencapai batas optimum. F2, F3 dan kontrol positif memberikan hasil \% penurunan diameter luka bakar hingga $100 \%$, F1 menunjukkan peningkatan $\%$ penurunan diameter luka bakar lebih cepat dibandingkan dengan kontrol negatif. Penelitian yang dilakukan oleh Farida dkk. (2011) juga menunjukkan ektrak etanol daun ubi jalar (Ipomoea batatas L.) mampu memberikan aktivitas penyembuhan luka bakar.

Hasil yang diperoleh juga diolah menggunakan uji parametik One Way Anova dengan syarat data yang diperoleh harus terdistribusi normal dan homogen. Hasil Uji One Way Anova menunjukkan p > 0,05 yang berarti F1, F2, F3, kontrol positif dan kontrol negatif tidak memberikan perbedaan yang signifikan secara statistik. Hal ini disebabkan karena rentang perbedaan konsentrasi terlalu kecil. Hasil pengamatan subyektif menunjukkan adanya perbedaan aktivitas penurunan diameter luka bakar pada F1, F2, F3, kontrol positif dan kontrol negatif.

\section{KESIMPULAN}

Fraksi etil asetat daun ubi jalar (Ipomoea batatas L.) memberikan aktivitas pengobatan luka bakar. Hasil statistik menunjukkan nilai $\mathrm{p}>0,05$ yang berarti tidak ada perbedaan signifikan secara statistik. Secara kualitatif penurunan luka bakar pada pemberian F2 dengan konsentrasi fraksi etil asetat daun ubi jalar (Ipomoea batatas L.) $2 \%$ memberikan aktivitas lebih tinggi.

\section{DAFTAR PUSTAKA}

Baud, S. G., Meiske, S. S. \& Harry, S.J. K. (2014). Analisis Senyawa Metabolit Sekunder dan Uji Toksisitas Ekstrak Etanol Batang Tanaman Patah Tulang (Euphorbia tirucalli L.) dengan Metode Brine Shrimp Lethality Test (BSLT). Jurnal Ilmiah Sains; 14; 106-112.

Cahyaningsih, N. (2018). Formulasi dan Evaluasi Sediaan Gel Minyak Atsiri Daun Jeruk Purut (Citrus hystrix DC.) dengan Basis HPMC Sebagai Antibakteri terhadap Staphylococcus aureus. Skripsi; Fakultas Farmasi Universitas Muhammadiyah Surakarta, Surakarta.

Draelos, Z. D. \& Lauren, A. T. (2006). Cosmetic Formulation of Skin Care Products. New York: Taylor and Francis Group.

Farida, R., Mimi, A. \& Nurwani, P.A. (2011). Formulasi Krim Ekstrak Etanol Daun Ubi Jalar (Ipomoeae batatas L.) untuk Pengobatan Luka Bakar.Scientia; 1; 21-26.

Fithriyah, N., Arifin, S. \& Santi, E. (2013). Lumatan Daun Sirih Merah (Piper crocatum) Terhadap Lama Penyembuhan Luka Bakar Derajar II pada Kelinci (Cavia cobaya). Dunia Keperawatan; 1; 24-31.

Ghofroh, A. A. (2017). Uji Aktivitas Ekstrak Etanol 70\% Daun Kitolod (Isotoma longiflora) terhadap Percepatan Penyembuhan Luka Bakar (Combustio) Derajat II pada Mencit (Mus musculus). Skripsi; Jurusan Farmasi UIN Maulana Malik Ibrahim, Malang.

Lestia, A. \& Marline, A. B. (2018). Review Article: Tanaman Obat yang Memiliki Aktivitas Terhadap Luka Bakar. Farmaka; 6; 51-59.

Muthmaina, I., Sri, H. \& Maifitrianti, W. S. (2017). Aktivitas Penyembuhan Luka Bakar Fraksi dari 
Ekstrak Etanol 70\% Daun Pepaya (Carica papaya L.) pada Tikus. Farmasains; 4; 39-46.

Nafisah, M., Suyatno, T. \& Nurul. (2014). Uji Skrining Fitokimia Ekstrak Heksan, Kloroform dan Metanol dari Tanaman Patikan Kebo (Euphorbiae hirtae). Prosiding; Seminar Nasional Kimia Universitas Negeri Surabaya.

Panji, G. P. (2017). Formulasi dan Uji Kualitas Fisik Sediaan Gel Getah Jarak (Jatropha curcas). Skripsi; Fakultas Kedokteran dan Ilmu Kesehatan Universitas Muhammadiyah Yogyakarta, Yogyakarta.

Rahim, F. M., Aria N. P. \& Aji. (2011). Formulasi Krim Ekstrak Etanol Daun Ubi Jalar (Ipomoea batatas L.) Untuk Pengobatan Luka Bakar. Scientia Journal; 1; 21-26.

Suhada, M., Farhandika, P. \& Gathut, P. (2019). Hubungan Antara Tingkat Kepatuhan Perawat Terhadap SOP (Standar Operasional Prosedur) Perawatan Luka Dengan Proses Penyembuhan Luka Pasien Pascabedah di RSUD dr. H. Andi. Jurnal Keperawatan Muhammadiyah; 4; 127135 .

Sulistyawati, R., Laela, H. N., Sholihatil, H., Ahmad,
M. \& Mustofa. (2016). Standarisasi Kualitas Fraksi Etil Asetat Daun Kelor (Moringa oleifera Lamk.). Journal of Pharmaceutical and Medicinal Sciences; 1; 30-35.

Ulfa, M., Wahyu, H. \& Prcilya, N. M. (2016). Formulasi Gel Ekstrak Daun Kelor (Moringa oleifera Lam.) sebagai Anti Inflamasi Topikal Pada Tikus (Rattus novergicus). Journal of Pharmaceutical and Medicinal Sciences; 1; 3035.

Widjaya, A. (2012). Uji Antifertilisasi Ekstrak Etanol $70 \%$ Biji Delima (Punica granatum L.) Pada Tikus Jantan Strain Sprague Dawley Secara In Vivo. Skripsi; Fakultas Kedokteran dan Ilmu Kesehatan UIN Syarif Hidayatullah, Jakarta.

Yulita, L. D. (2018). Perbedaan Kecepatan Pemyembuhan Luka Bakar Derajat II Antara Pemberian Topikal Ekstrak Sel Punca Mesenkimal Wharton's Jelly Tali Pusat Manusia dengan Gel Bioplacenton Pada Tikus Putih Jantan (Rattus norvegicus) Galur Sprague dawley. Skripsi; Fakultas Kedokteran Universitas Lampung, Bandar Lampung. 